\title{
The Meaning of Millennial Generation Text: Reception Analysis of \#KidsJamanNow
}

\author{
Ririn Puspita Tutiasri ${ }^{1}$, Syafrida Nurrachmi Febriyanti ${ }^{2}$ \\ 1ORCID iD: 0000-0003-3050-3744, Universitas Pembangunan Nasional "Veteran" \\ Jawa Timur, Jl. Raya Rungkut Madya, Gunung Anyar, Surabaya, \\ East Java 60294, Indonesia \\ 2ORCID iD: 0000-0003-2420-8466, Universitas Pembangunan Nasional "Veteran" \\ Jawa Timur, Jl. Raya Rungkut Madya, Gunung Anyar, Surabaya, \\ East Java 60294, Indonesia \\ *Corresponding author, e-mail: ririn_puspita.ilkom@upnjatim.ac.id
}

\begin{abstract}
The term 'Kids Jaman Now' (Children Today) appears on various social media sites through content that represents the activities of young people in the current era. There are more than 1.6 million pieces of content on Instagram and more than 270 thousand pieces of content on YouTube which use the hashtag 'Kids Jaman Now'. Through these contents, young people are perceived as a narcissistic, individualistic generation with a setback in moral values. This study uses reception analysis by conducting in depth interviews on a number of millennial generation informants who consume 'Kids Jaman Now' contents to find out how they interpret the content. This study aims to show that young people who use social media are not consumers who receive messages passively; they have critical power towards the content they consume as digital natives who have better literacy than previous generations. The millennial generation has three different acceptances of this phenomenon. The first considers the content of 'Kids Jaman Now' to represent a narcissistic, individualistic, and deteriorating moral values generation. The second considers 'Kids Jaman Now' content as creativity for young people who entertain others and master digital communication technology.
\end{abstract}

Keywords: Kids Jaman Now, Social Media, Millenial Generation, Reception Analysis.

\section{Introduction}

'Kids Jaman Now' (Children Today), is a criticism or satire towards the younger generation, thus changing the word era into era. The word 'today's' shows that children already existed in the 1970s, as seen in the song "muda-mudi" belonging to Koes Plus which reflects how young people behave in 'present times' (Syukron, 2018). Nowadays, the term 'Kids Jaman Now' has become viral again because many people think that young people are stylish with a strange appearance and wish to be famous. Through information technology or social media, children upload their strange behavior with the aim of getting lots of likes, views, and followers. People also use social media to criticize their strange behavior with the hashtag \#kidsjamannow. Social media sites such as Youtube and Instagram upload a lot of photos and videos of the strange behavior of 'Kids Jaman Now.' The previous generation, or the millennial generation, considers 'Children Today' as a different generation; even as a tacky generation (Syukron, 2018). The term 'Kids Jaman Now' first appeared because of the strange actions carried out by Generation Z. The depiction of 'Kids Jaman Now' emerges in a music clip video by Ecko Show. The video with the title 'Kids Jaman Now' describes children's behavior today, which is quirky, strange, funny, and sometimes concerning. This video has gone viral on Youtube and Instagram with the hashtag \#kidsjamannow. Two weeks after it

Article History: Received October 31, 2019; Revised November 29, 2020; Accepted December 01, 2021; Published December 28, 2021 
was uploaded, it reached 1.7 million views. After three years of uploading, this video has had more than 4 million views.

Technology in the field of information and communication has the ability to change people (Ashrianto \& Yustitia, 2020). For example, technology changes human behavior in lifestyle and culture (Tutiasri \& Kusuma, 2020). In the past, humans knew each other through physical meetings, sending letters, and making phone calls, but now humans only need to open social media to assess how things are going (Candrasari, 2021). Positive impact of these technological advances can be felt if the users utilize the technology correctly and responsibly (Vromen et al., 2015, Zulfah, 2018). Information revolution occurs while using technology because it allows human life to change (Ahmad, 2012). Utilization of technology or the internet consists of layers of generations (Medcom.id, 2017). The existence of a multi-directional and complex flow of interaction is part of the interaction on social media, and through digital technology in the form of plates and profiles is used together and tied to one another (Schwartz et al., 2012). Technological users are diverse. According to data, internet users in Indonesia in the second quartile of 2020 total 196.7 million or $73.7 \%$ of the population in the country, or up to 25.5 million which is higher than last year (Jatmiko, 2020). Below are the categories of internet users according to the age and generation:

Table 1. Generation Grouping

\begin{tabular}{cccccc}
\hline Source & & \multicolumn{4}{c}{ Label } \\
\hline Tapscott (in & & Baby Boom & Generation & Digital & \\
Jatmiko, & - & Generation & X & Generation & - \\
2020) & & $(1946-1964)$ & $(1965-1975)$ & $(1976-2000)$ & \\
Howe \& & Silent & Boom & 13th & Millenial & \\
Strauss (in & Generation & Generation & Generation & Generation & - \\
Jatmiko, & $(1925-1943)$ & $(1943-1960)$ & $(1961-1981)$ & $(1982-2000)$ & \\
2020) & & & & & \\
Zemke et al. & Veterans & Baby & Gen-Xers & Nexters & \\
(in Jatmiko, & $(1900-1943)$ & Boomers & $(1960-1980)$ & $(1980-1999)$ & - \\
2020) & & $(1946-1964)$ & & & \\
Lancaster \& & Traditionalist & Baby & Generation & Generation & \\
Stillman & $(1900-1945)$ & Boomers & X & Y & - \\
(in Jatmiko, & & $(1946-1964)$ & $(1965-1980)$ & $(1981-1999)$ & \\
2020) & & & & & \\
Martin \& & Silent & Baby & Generation & Millenials & \\
Tulgan & Generation & Boomers & X & $(1978-2000)$ & - \\
(in Jatmiko, & $(1925-1943)$ & $(1946-1964)$ & $(1965-1977)$ & & \\
2020) & & & & & \\
Oblinger \& & Matures & Baby & Generation & Gen-Y/ & Post \\
Oblinger & $(<1946)$ & Boomers & Xers & NetGen & Millenials \\
(in Jatmiko, & & $(1947-1964)$ & $(1965-1980)$ & $(1981-1995)$ & $(1995-$ \\
2020) & & & & & Present) \\
\hline
\end{tabular}

Note: Generational grouping according to various sources

This categorization is based on two factors: demography and sociology. Parry \& Urwin (2011) stated that the later factor is rather interesting as the background of research is either for study or the difference of generations. The number of internet users in Indonesia has increased because internet provides easy access and contains any information. The millennial generation and 'Kids Jaman Now' a group that uploads 
their daily activities on social media, are a creation of internet. The millennial or Y generation is the generation which utilizes social media frequently such as through email, SMS, instant messaging, and other social media (Putra, 2018). This generation also receives and takes advantages from the development of technological information (H. Chen, 2018). They learn step by step through books or another manual both for software and hardware technology. The age of this generation ranges from 19 to 34 years old (Hidayatullah et al., 2018). According to Yuswohady (2016) in his article titled Millennial Trend of Millennial Generation, the millennial generation were born between 1980 and 2000, the year of millennium disposition.

'Kids Jaman Now' were born at the time when technology was already a part of human lives. 'Kids Jaman Now' is the generation of internet users from the age of 12 to 18 years old, categorized as the Z generation (Duntari \& Riska Hidayat, 2018). 'Kids Jaman Now' refers to children and teenagers who are currently in the state of identity searching. 'Kids Jaman Now' becomes a new label for children today to differentiate themselves with the former generations. 'Kids Jaman Now' is already familiar with using technology and social media. 'Kids Jaman Now' is originally from the term 'Children Today' which is seen as a factual topic now (Syafrida Febriyanti, 2019). 'Kids Jaman Now' is almost entirely influenced by the development of gadget technology. Community perceptions have grown into some negative perspectives towards children today, more so than the kids from the previous generation, and specifically with anything related to morale (Fiaji, 2018)

Children today spend most of their time playing with their gadget. The term 'Kids Jaman Now' started to be popular since it was published by an observer and children psychology Seto Mulyadi (Duntari \& Riska Hidayat, 2018). These children appear after the millennial generation but both generations are active in the use of social media. What makes both generations different are that the millennial generation recognizes the internet since their teenage years whereas the 'Kids Jaman Now' were aware of internet since they were children. Parents of 'Kids Jaman Now' have introduced entertainment and games from gadgets connected to internet for these children, even when they were babies. Thus, 'Kids Jaman Now' has grown accustomed to internet and social media applications.

With an aim to become a trending topic and amass many likes and followers, children can post anything they like on social media. The number of likes (a heartshaped sign to express fondness or agreement) and followers (of the account) stand as an achievement or as a sign that many people are inspired by the individual's content (Gangneux, 2019). Children nowadays do not need to join an audition or dress as cool as possible in order to be popular or praised by people; they only need to upload their work to social media through their smart phones. If the uploaded contents are unusual and interesting, usually there will be many people who like and follow the account. The hashtag 'Kids Jaman Now' makes it easier for a child to be popular and get many followers on social media. Use of a hashtag can indicate which style a child is imitating for social media to make them an idol or a follower.

Many see 'Kids Jaman Now' as a generation which tends to negativity as they are busy with their own world, doings, works, and are obsessed with being popular or becoming viral instantly. (Musya'adah, 2018) have defined these children as kids who misbehave. This generation seems to have disoriented lives with no purpose of living (Soerjoatmodjo, 2018). According to this generation, doing anything without considering whether the action is right or wrong is acceptable if they can become viral. 
This led to the perception that 'Kids Jaman Now' is a negative term, and there is even a new term called 'generasi micin' (MSG generation). MSG, a kind of food flavor enhancer, is considered to cause cognitive ability degradation when it is consumed constantly, and there are countless foods which contain MSG nowadays. 'Generasi Micin' is strongly related to 'Kids Jaman Now,' a group of youths who do unusual things in order to be popular instantly. There are many pictures or videos posted on social media which show things they do: from their fashion style, the way they talk, and even the way they act like adults. One example of how children act like adults is when they shamelessly show their affection towards their girlfriend or boyfriend as if they are adults. There are many memes which portray the negative behavior of 'Kids Jaman Now,' when there are children who exhibit inappropriate actions, they will easily be called 'Kids Jaman Now.'

Both the millennial generation and the 'Kids Jaman Now' generation are fond of accessing social media, especially YouTube and Instagram. In Indonesia, YouTube is becoming increasingly popular with up to 143.26 million users or $54.7 \%$ of the population in 2018. While Instagram is the most popular social media in the world with users aged 25 to 34 years, in Indonesia this application is in third place after YouTube and WhatsApp, with the most users aged 18 to 24 years (Nurhadi et al., 2020) explained that YouTube is a video sharing social media application; it allows the users to watch videos of other users and is a widely popular social media site. The content of YouTube includes movies, short films, musics, musical videos, vlogs, and educational videos (C.P. Chen, 2014; García Jiménez \& Montes Vozmediano, 2020; Khan, 2017). From Palinoan (2017), YouTube users must be registered or are unable to watch various video contents of creators on YouTube. YouTube audiences range from 18 to 34 years old and there are more users within 18 to 49 years old than other networks (Faiqah et al., 2016). Videos on YouTube Content are often re-shared on Instagram social media accounts, so videos about 'Kids Jaman Now' are viral on YouTube and Instagram.

Different habits between children in the current and the previous generations are the outcome of high technology. Children today can get information, entertainment, and present their existences to be the center of attention through internet. This is contrary to the children from previous generations who spend most of their time playing with other children, helping their parents, or participating in events to socialize. A research of Bencsik \& Machova (2016) shows the differences between Gen $\mathrm{Z}$ and the previous generation in utilizing and mastering information as well as the technology in their lives. Because Gen $\mathrm{Z}$ was born when internet access had become part of global culture, high technology has influenced the values and perspectives of their lives. A study conducted by Suryadi (2015) presented Gen Y's positive behaviors, such as their concern for new technology, eagerness for change, high creativity, intelligence, the fact that they are full of ideas, and their reliability. This study not only looks at the acceptance of the 'Kids Jaman Now' phenomena but also observes millennials' interpretation, comprehension, and perspective regarding the phenomena. This research is interesting because the two generations presented are already internet literate, especially in using YouTube and Instagram as media to find information, entertainment, education, and to exist in.

Many studies have discussed the millennial generation and generation Z. One of which is research about the Millennial generation and family literacy within the dissemination of hoaxes in Whatsapp groups. Here, the millennial generation provides literacy on using social media about hoaxes to the baby boomer generation (Tutiasri \& 
Kusuma, 2020). In comparison, research towards generation $\mathrm{Z}$ examines the relevance of communication changes due to changes in technology. Changes in activity can have implications for cultural contradictions and societal norms (Akqmie et al., 2021). The research above shows changes due to technology in every generation of humans. Changes in this technology can also lead to war or conflict.

Interestingly the millennial generation is always involved in this feud. In the past, a feud between the millennial and baby boomer generations emerged the term "OK, Boomer". The feud was resolved by understanding mutual respect between generations (Nuriana et al., 2019). The feud between generations keeps happening, and the millennial generation remains the main character since this generation is fans of technology. The feud this time is different, involving the younger generation, generation Z. Interestingly, this intergenerational feud is very striking in Indonesia. The Indonesian millennial generation has created an allusion to children today with the word 'Kids Jaman Now' to show their dislike for Generation Z. This research is intriguing. Because the feud between these two generations, which is very popular, shows how the millennial generation receives video uploads on Youtube and Instagram with \# (hashtag) 'Kids Jaman Now.'

\section{Methods}

This study uses in-depth interviews as a qualitative research method to obtain comprehensive data regarding the acceptance of the millennial generation to the 'Kids Jaman Now' phenomenon, in videos both on YouTube and Instagram that use the hashtag (\#) 'Kids Jaman Now.' This study aims to obtain data authentically through accurate analysis techniques. As stated by Bungin (2013), this research refuses to seek and explain the relationship but emphasizes more on scientific observations and data. The informants of this research are millennials who are active users of YouTube and Instagram and are related to 'Kids Jaman Now.' In this study, the informant watched a video with the title 'Kids Jaman Now' on Youtube by Ecko Show along with Ecko Show Instagram accounts and his other accounts that post videos with the hashtag (\#) 'Kids Jaman Now' illustrate how Generation $\mathrm{Z}$ behaves. There are two categories of millennials, namely students and workers.

Table 2. Information of Millennial Informants

\begin{tabular}{crcc}
\hline No & Age & Amount & Percentage \\
\hline 1. & $<19-23$ & 9 & 56,25 \\
2. & $23-35$ & 7 & 43,75 \\
& Total & 16 & $100 \%$ \\
\hline
\end{tabular}

Note: The informants in this study

The data analysis method for this research is based on the acceptance of the millennial generation on the social media platforms YouTube and Instagram, which show the phenomenon of "Kids Jaman Now." The signs were analyzed using the reception analysis model (Hall, 1997) which was concluded into three possibilities: 1) the hegemonic position is characterized by audience acceptance of the idea of 'Kids Jaman Now' on YouTube and Instagram; 2) the negotiating position is characterized by viewers negotiating messages in the media about 'Kids Jaman Now' on YouTube and Instagram; and 3) however, conflict persists in the audience due to the actions of 'Kids Jaman Now' about what to do or what not to do and what to control. Opposition is the disapproval or rejection of the idea of videos with the hashtag (\#) 'Kids Jaman Now' on YouTube and Instagram. 


\section{Results}

In this study, researchers interviewed two categories of millennials: students and graduates. With this category, researchers are moved to observe the overall acceptance of 'Kids Jaman Now.' This study found three results, namely how millennials use YouTube and Instagram, the millennials' acceptance of the 'Kids Jaman Now' phenomenon, and how 'Kids Jaman Now' is considered an instant generation. In this study, access to YouTube usage was divided into three: more than three hours, two to three hours, and less than one hour. The quotes obtained are as follows: "Usually before going to bed, I have nothing to do, so I watch YouTube and Instagram until three hours" (Hertin, female, 25-years-old); "From four in the afternoon to ten at night" (Shela, female, 26-years-old); "Every time I got a Wi-Fi, I certainly watch YouTube" (Fajar, male, 22-years-old); "If I hardly have anything to do, usually, it is four hours, from midnight till dawn" (Resa, female, 25-years-old). The five informants describe that they use more than three hours of their time in a day to access the internet and that they spend their free time watching video shows both from Youtube and from Instagram. Youtube and Instagram users spend more than two hours due to the ease of accessing the internet, such as the availability of Wi_Fi, and both social media are effortless to access. Social media is designed as a user friendly and efficient platform (Rahman et al., 2021). Youtube and Instagram users spend much time watching videos as entertainment in their spare time.

The second group consists of informants who access the internet two to three hours a day, use the internet for entertainment only when they have free time, and still consider their daily activities while studying. The quotes obtained are as follows: "I only access the internet when I have college assignments, only about two to three hours, and even then I open YouTube, Instagram, and other social media applications that I have" (Aisyah, female, 22-years-old); "I look at social media, do college assignments, make posts in a day I spend less than three hours accessing the internet in a day" (Ferdy, male, 22-years-old). From the above, most of the informants who are still in college answered that they use the internet as entertainment when they finish college, for various needs from studying or doing college assignments or updating new things, especially related to the latest information. There is one informant who observes that the content on one social media platform is also easily spread to other social media platforms.

The third group consists of informants who answered that they use the internet for less than one hour a day, giving the following reasons: "I access the internet for less than an hour a day, I spend more of my time hanging out with my friends" (Rachel, male, 21-years-old); "I often open my smartphone in my daily life when I get instant instant messages on my social media, if in a day how long I stare at my device, maybe less than an hour" (Wendra, male, 21-years-old). The two informants who use the internet for less than an hour explained this was because they access the internet according to their needs; they open the internet when answering messages and otherwise spend time doing daily activities playing with or meeting friends in the real world.

These discoveries are interrelated; the millennial generation is seen from the view of 'Kids Jaman Now' as a sign of cultural change and the use of technology through video shows on YouTube and Instagram social media. Teenagers watch Youtubers and they identify themselves with the same things; they follow these shows because they receive entertainment and learn (Pires et al., 2021). In terms of using technology, 'Kids 
Jaman Now' is different from the millennial generation; they only need to observe without having to study or read tutorials on how to use tools and applications. The millennial generation likes how YouTube users, who are often called YouTubers, share tips that they can imitate. Children give tips and share experiences that are often imitated or applied mostly in their daily routines (C. Scolari et al., 2018): "I'm more into films and tutorial, like how to use a camera or edit a video" (Rifky, male, 22-yearsold). Youtubers have the ability to entertain or participate in amateur aesthetics, as in the traditional celebrity system (C. A. Scolari \& Fraticelli, 2017).

Researchers discover a new phenomenon in which millennial generations tend to seek information that is educational or that which provides directions such as the following: "I watch beauty vlog" (Indah, female, 25-years-old); "So do I, I also subscribed Mata Najwa" (Sheren, female, 23-years-old); "I like watching beauty tutorials and handcraft tutorials" (Resa, female, 25-years-old); "I watch unboxing electronic gadgets vlog, tutorials, and Naruto series" (Deny, male, 23-years-old); "Most of the time, I watch editing tutorials or so Mostly, I like beauty vlogger or Korean reality shows" (Shela, female, 26-years-old). In addition to the benefits of collecting information or learning from media through video tutorials, making the millennial generation take advantage of social media, especially the sites of YouTube and Instagram through hashtags (\#) or suggestions when viewing video posts is shown in the following: watching movie trailers while playing games, check the trends, watch music or dancing videos YouTube channel, watching unique things like device, recommendation videos appear to be good. Millennials access entertainment, information, and even tutorials from social media from suggestions given via hashtags (\#) or for videos on YouTube or Instagram via next video suggestions (Aydin et al., 2021; Mosley et al., 2017). Hashtag usually consists of a series of characters (possibly including numeric numbers) preceded by the pound symbol (\#) which is also called a hash). This combination has function as a label for the message itself and 'linked to a search for those characters' (Mulyadi \& Fitriana, 2018).

From the video display, both from the hashtag (\#) and from video suggestions, a viral video emerged with the hashtag 'Kids Jaman Now,' where millennials accept this phenomenon with different receptions: 'Kids Jaman Now' are young Indonesians who in are still in gen $\mathrm{Z}$ or were born in the millennial generation, so they are tech-savvy and in their daily lives they are always being attached to technology. It's almost the same; personally, young people are more tech-literate like today.

The following is the answer of the millennial generation who perceive 'Kids Jaman Now' as negative influence: 'The behavioral patterns of children who follow technology can be predicted according to what they are watching, so when they watch something beyond their age, now they start misbehaving, for instance is Bowo" (Fajar, male, 22-years-old); "Yes, they are precocious because of technological advance, children tend to follow the trends through technology and become precocious" (Dwidwiki, male, 26-years-old); "Underage children who behave inappropriately unlike their age, for example, from their dating style, they are already called each other mama-papa" (Shela, female, 26-years-old). The children's perspective follows the era of globalization, so the impression tend to be more negative, so it is like what friends think because most of them are mostly imitate the bad one than the good. Children today are creative, but their creativity is shifted to negative things like those that are currently happening, gathering to meet and great and others. 'Kids Jaman Now' are not very selective they only follow what's viral. 'Kids Jaman Now' not much different from 
the others, kids nowadays, we just can't take the negatives, even though there are many positive sides of them, for example, a lot so kids now are more tech-savvy and more updated to new things, like they know more about technology than the previous generation.

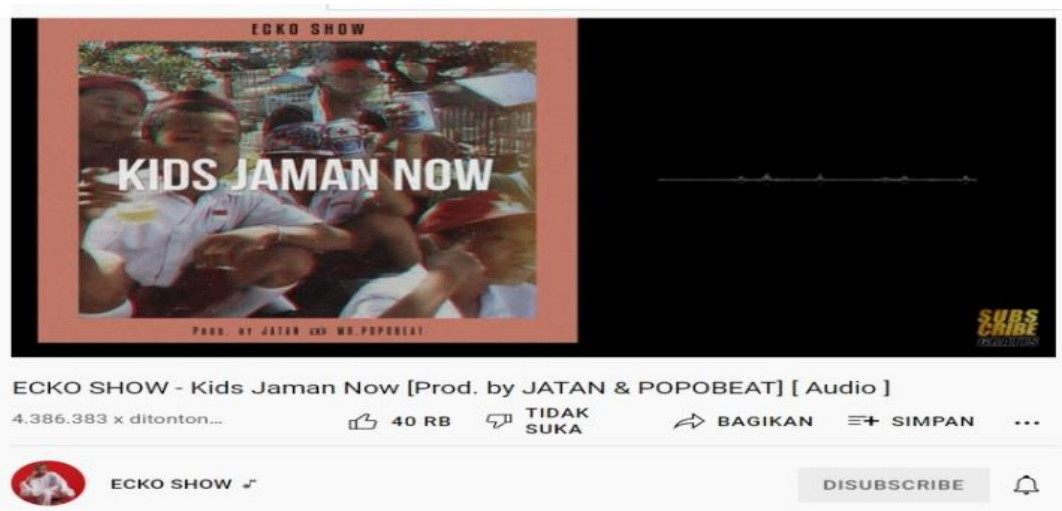

Figure 1. screen capture of the Ecko Show on his YouTube account (source: youtube.com/watch? $\mathrm{v}=\mathrm{zWN} 5 \mathrm{nCYDtpk}$ )

The findings above are how the phenomenon of 'Kids Jaman Now' is accepted by the millennial generation on social media. Meanwhile, this is how the millennial generation react when they get to know 'Kids Jaman Now' closely: "I have a younger sibling, she is going to high school with advanced digital system, she can also be called 'Kids Jaman Now' and she is rather stubborn. As an example if my parents tell them to study, recite Al-Qur'an, have a prayer, she is always being difficult and refuted, and so her behavior changes not in a positive way. As the time went by, she becomes more difficult and stubborn than before, it does not rule out the possibility that their friends behave the" (Indah, female, 25-years-old). 'Kids Jaman Now' these days are more concerned with their social life on social media than their everyday life in their environment. Children these days, few has already had Instagram and YouTube accounts at the age five, even though the YouTube account only reviews.

"My own nephew, who is still in playgroup, jokes like an adult, like when a boy says he has girlfriend, and when I ask him who taught him to talk like that, he said he saw it from TV and YouTube. The problem may also be the fault of their parents if they leave their children to work and give them a cellphone so they can watch at will. Mothers also usually like watching soap operas than educational content and watching it with their underage children. Meanwhile, I myself know that my girlfriends started dating from elementary school and it's still embarrassing" (Shanti, female, 26-yearsold). 


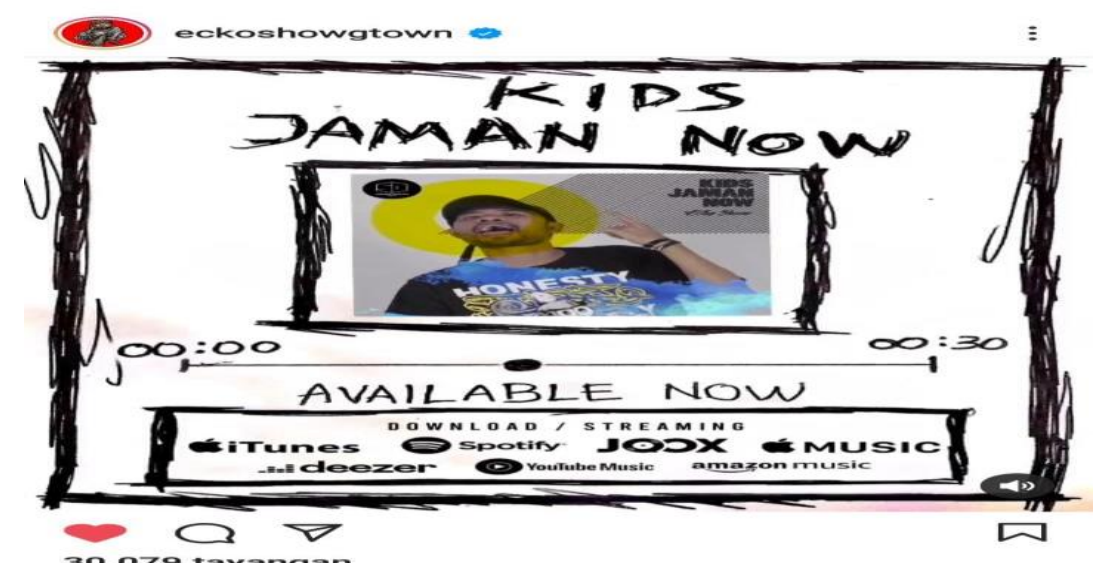

Figure 2. eckoshowgtown's Instagram post on January 06, 2020

(source: instagram.com/eckoshowgtown/)

"'Kids Jaman Now', it's like craving for popularity and attention, for example, my younger brother is still in high school, and I thought he was studying yet he took a record his followers on Instagram, who did not follow him back yet" (Wendra, male, 21-years-old); "Yes, there is my nephew, so if you are fussy, look at YouTube, if you have given YouTube, he is no longer fussy. Usually, he watches the tutorial for making slime or watching Barbie cartoons and he prefers watching YouTube than playing with his friends so if he doesn't watch YouTube, he cries" (Deny, male, 23-years-old). Traditional celebrities are easily identified by their talents; however, on the other hand, social media celebrities offer various distinctions, apart from their talents (Khamis et al., 2017; Lee \& Kim, 2020; Rahmawati, 2021). 'Kids Jaman Now' wants instant fame by observing what goes viral and then copying it. Whether what they imitate is good or not, their main goal is getting acknowledged by other media users. There is a positive side taken from 'Kids Jaman Now'; they understand media use faster and imitate faster. Seeing and imitating good things can result in a positive impact. "I have a friend in Jakarta, he already has a channel to review cellphones and he's already earning more than 3 million per month, he has a team of 6 people, so there is a cameraman, an editor, a reviewer and the script writer. That's better for him than he used to be, which was being unemployment" (Rifky, male, 22-years-old). The positive thing is that they can earn money from YouTube, so if they have talent like singing, then creating a YouTube channel is like practicing their skills, if they want to channel their talents they can do it.

In this research, the researchers interviewed two categories from the millennial generation: students, and graduated students/workers. Within these categories, the researchers were intrigued to observe the acceptance of 'Kids Jaman Now' thoroughly. This study discovered three results: how the millennials utilized YouTube, the acceptance of millennials to the 'Kids Jaman Now' phenomena, and how 'Kids Jaman Now' was considered to be the instant generation. These discoveries were related to each other; the millennial generation personally perceived 'Kids Jaman Now' as a sign of the changes in culture and technology information utilization. In the sense of utilizing technology, 'Kids Jaman Now' are different from the millennial generation as they only need to observe without necessarily learning or reading tutorials on how to use tools and applications. 'Kids Jaman Now' is an instant generation which has negative and positive impacts. The following is a discussion of the results of research related to the acceptance of the millennial generation with the phenomenon of 'Kids Jaman Now.' 


\section{Discussion}

Millennial Generation, Content on Instagram and YouTube

The millennial generation has followed the evolution of technology throughout generations. They have grown up with technological evolution, from $1 \mathrm{G}$ technology which only received voice calls, $2 \mathrm{G}$ capable of receiving text and voice calls, $3 \mathrm{G}$ receiving voice call, message, and data, and finally, $4 \mathrm{G}$, which is a technology able to connect the internet to ease the access to information, entertainment, education, and more. Informants in this research spend mostly two hours of their time on YouTube and Instagram.

These answers came from millennials who graduated: they spent between three to unlimited hours on YouTube. They enjoy the technological advances due to their financially independent condition (Raby et al., 2018). Millennials are the future of generations who are already accustomed to a new media culture environment (Ibrahim, 2011). They are characteristically interactive, individual, computer-literate, and communicate personally. Millennials or digital natives have grown in an era of internet culture (Supratman, 2018).

The rests gave the same response; they accessed YouTube between two and three hours daily (Rosidi, 2020). Informants who spend two to three hours on the internet are diverse millennials; some of them are in college and others are already employed, while the other respondents with access on YouTube of less than two hours come from millennials with student status.

The usage of YouTube and Instagram from several informants was divided into three categories: less than two hours, more than two hours, and accessing YouTube and Instagram at any time depending on the need. McQuail (West \& Turner, 2014) explained that the identity of media users involves ways to emphasize individual values as a reinforcement of personal identity for all informants who access YouTube and Instagram social media for entertainment and information. The existence of a new habit refers to the behavior of people who use telecommunications aids. The dependence on telecommunications equipment has become very high (Naldo, 2018). From watching YouTube, informants also revealed their preferred genre of entertainment on YouTube. The informants' chosen genres are very diverse, ranging between video tutorials, unboxing videos, video clips, music, vlogs, and educational videos.

A way of thinking by constructing a meaning according to the ability or from the cognitive capacity that contains information (Ellison et al., 2014; Prianto, 2014) has led video tutorials to provide knowledge to the millennial generation to learn new things. The millennial generation has a great potential to help develop the Indonesian nation if they can carry out productive activities in the fields of education, health, economy, and government (Kuncoro et al., 2018). If the millennial generation looks for positive things and imitates them, a good impact from technology will be seen. Rootsi et al. (2013) explains that there are aspects in supporting one's self-concept, self-knowledge, and self-esteem that may affect oneself (Sianipar, 2013). YouTube is a database that contains popular video content as well as being a provider of various information for both video and live streaming.

Indonesians are looking for entertaining and fun but informative content; it is still rare for internet users to fully use YouTube as a source of getting information to increase knowledge in an academic field (Adib, 2011). Technology also affects the progress and development of a nation. YouTube is an information technology that is able to provide a new color for Indonesians, especially the millennial generation that has 
started to leave behind television shows and instead turned into connoisseurs of YouTube content. Videos on YouTube are video clips of films, television shows, and the users themselves (Widika, 2018).

The Acceptance of Millennial Generation to 'Kids Jaman Now' on Instagram and YouTube

The millennial generation and 'Kids Jaman Now' are consecutive generations; both generations are very adept at using technology. The difference is when millenias use technology or access information, they read or pay attention to the existing instructions or rules. It's different from 'Kids Jaman Now,' who are adept at accessing and using technology because of their abilities or habits since childhood. The phenomenon of 'Kids Jaman Now' is a generation that naturally arises because they have been accustomed to accessing technology. There are three kinds of acceptance from the millennial generation when seeing the phenomenon of 'Kids Jaman Now': first, perceiving 'Kids Jaman Now' as a negative generation because they behave inappropriate regarding their age. Second, 'Kids Jaman Now' is positive because they are media-literate and more sophisticated than the millennial generation. Third, millennial generations are neutral to the 'Kids Jaman Now' phenomena because they perceive that both negative and positive impacts exist due to this phenomenon.

The negative view of 'Kids Jaman Now' is a perception of society regarding negative prejudices against children today compared to children in previous generations, which is related to morals (Fiaji., 2018). Self-control is necessary to help someone to behave accordingly so that they respect others and avoid aggression. The lower the selfcontrol is, the higher the aggressiveness, and vice versa (Denson et al., 2012). This is from the pattern of behavior, especially with regard to the morale of the millennial generation in accepting the presence of 'Kids Jaman Now' as an immature generation, both from the content they watch, access to technology, and how to interact with people. At a young age, 'Kids Jaman Now' greet people inappropriately, such as using the words daddy or mama as nicknames when they like someone. Even dating or having a relationship without ties in the millennial generation is taboo, but in 'Kids Jaman Now' it is not a problem that indicates a cultural shift.

There were two informants who answered that the 'Kids Jaman Now' is recognized as a positive phenomenon; they admit that kids today are superior at accessing technology and information over the millennial generation. 'Kids Jaman Now' is accustomed to accessing technology because of their daily life, and since childhood they are used to living in a cultural and technological environment.

The millennial generation considers 'Kids Jaman Now' as a generation of misconduct; they believe they should have grown up with the love of their parents and loved ones, but instead they grew up under the care of technology. Parents of 'Kids Jaman Now' want to present the best future for their children, thus since childhood their children have been trained in media literacy. Even though the growing patterns of adolescents can behave positively or negatively depending on the children's parenting patterns (Duntari \& Riska Hidayat, 2018), 'Kids Jaman Now' are similar to any children in previous generations; they have negative traits and positive traits. The difference is that they find the meaning of life from what they see without restrictions. They saw what they shouldn't have seen (Yusuf, 2016). There is an individual learning process by adjusting oneself to the norms, morals, and traditions of the group, which merges into one unit and communicates with each other. Watching videos through technology, especially YouTube and Instagram, leads the 'Kids Jaman Now' to learn about values, 
norms, morals, and even traditions. They adopted what they saw as a guide to finding meaning in life. There are no restrictions and controls as to who forces 'Kids Jaman Now' to feel that their spectacle is a model of their life (Suherman, 2016). An individual should avoide situations that can bring out individual characteristics; he should not allow himself to act negatively (Syam \& Nurrahmi, 2020).

There are various responses from the millennial generation towards the phenomena; some have a close relationship so they can observe their daily lives. 'Kids Jaman Now' is a generation where technology is well-recognized, but according to the disclosure of the millennial generation, informants regard this phenomenon as a misbehaving generation that is difficult to manage.

'Kids Jaman Now' are drawn for popularity; they are looking for identity from YouTube or other media (Instagram) to analyze whether the environment around them supports them or not. Addiction to technology has begun to appear when they prefer to be quiet with their devices rather than playing with their peers. YouTube is one type of media that enchants 'Kids Jaman Now' deeply, because of its interesting audio-visual shows. In addition, connoisseurs of YouTube content can replace their content with an interesting theme.

\section{'Kids Jaman Now': The Instant Generation}

YouTube and Instagram media makes users independently learn by tinkering with video content and making it a better quality piece of media (Faiqah et al., 2016). YouTube and Instagram encourages 'Kids Jaman Now' to grow into an instant generation; the kids watch the shows and are capable of imitating them. The following work shows the acceptance of millennials towards the kids of the instant generation after seeing YouTube and Instagram shows.

Apart from the negative impact of 'Kids Jaman Now' they have also gained achievements and even become famous and rich instantly. They subscribe/follow to YouTube and Instagram account or create their own channel. The achievements of 'Kids Jaman Now' are very diverse and by doing the following they get certain benefits: tutorials, reviews, editing videos, selling goods, publishing their talents, playing games, or uploading their own works on their channel. By uploading videos on a YouTube and Instagram account, the owner of a YouTube and Instagram account is assured that information can be spread and accepted by everyone via the internet network (Sari, 2020). The contents on YouTube and Instagram spread easily and engage other viewers, especially the current generation who will follow 'Kids Jaman Now' and discuss who has been successful before. They learn the success of their predecessors has been instant and they wish to imitate this (Rashid et al., 2020).

Correct and proper usage of YouTube and Instagram is significant, which is why it is important to guide and supervise the content of 'Kids Jaman Now' on YouTube and Instagram. There was a suggestion from one of the informants who stated that it is better to show about 'Kids Jaman Now'; therefore 'Kids Jaman Now' can filter the content they watch according to their age. This is very important because it will certainly affect how kids learn about life. After watching a YouTube and Instagram program, there are suggestions for the next video which the audience may be interested in watching, which is also important.

Many social media sites, especially YouTube and Instagram, have become a tool through which to find someone's identity or existence. However, there must be boundaries that regulate the content. This issue blurs the boundaries between real life and virtual life (Faiqah et al., 2016). Assistance and guidance from parents or the 
surrounding environment of 'Kids Jaman Now' when they access or use technology is ultimately necessary; adults should teach children how to filter the good information they get. When using YouTube and Instagram, parents also need to set some boundaries and controls. The existence of YouTube and Instagram for kids helps parents to provide information and entertainment for their kids.

\section{Conclusion}

This paper provides an overview of attitudes of the millennial generation toward the phenomenon of 'Kids Jaman Now' content which is widely circulated on Instagram and YouTube. They have three different acceptances of this phenomenon: the first considers the content of 'Kids Jaman Now' as a representation of a generation that is narcissistic, individualistic, and experiencing a decline in moral values. The second considers 'Kids Jaman Now' content as a form of creativity for young people who entertain and master digital communication technology. The third is more neutral and assumes that 'Kids Jaman Now' is just content and cannot be generalized as a representation of the character and identity of young people in Indonesia. In the end, this research shows that young people who use social media who receive messages passively have critical power to the content they consume as digital natives who have better literacy than before. This study reveals how the millennial generation's reception of changes in the use of technology by 'Kids Jaman Now.' This paper intends to inspire other researchers to examine every generational development and the advance of technological usage.

\section{Conflict of Interest}

We certify that there is no conflict of interest with any financial, personal, or other relationships with other people or organization related to the material discussed in the manuscript.

\section{Acknowledgements}

The author would like to thank the millennial generation informants for their contribution to discussing videos with the hashtag (\#) 'Kids Jaman now', and the Universitas Pembangunan Nasional "Veteran" Jawa Timur, Communication Science Study Program which has supported and facilitated researchers in this research.

\section{References}

Adib, M. (2011). Filsafat Ilmu: Ontologi, Epistemologi, Aksiologi, dan Logika Ilmu Pengetahuan, Yogyakarta: Pustaka Pelajar. Fil-Safat Ilmu: Ontologi, Epistemologi, Aksiologi, dan Logika Ilmu Pengetahuan. Pustaka Pelajar.

Ahmad, A. (2012). Perkembangan Teknologi Komunikasi dan Kesenjangan Informasi: Akar Informasi dan Berbagai Standarnya. Jurnal Dakwah Tabligh, 13(1), 137149.

Akqmie, N., Latiff, A., \& Kee, C. P. (2021). Mediatisasi dan Budaya: Pengalaman Peminat Gen Z Gelombang Korea Malaysia Mengharungi Pandemik Global Covid-19. Jurnal Komunikasi: Malaysian Journal of Communication, 37(1), 314333. https://doi.org/10.17576/JKMJC-2021-3701-18

Ashrianto, P. D., \& Yustitia, S. (2020). The Use of Social Media in Searching for Information about Papua. Jurnal The Messenger, 12(2), 122. https://doi.org/10.26623/themessenger.v12i2.1939 
Aydin, Z., Fuess, A., Sunier, T., \& Vázquez, A. G. (2021). The web of hate: Fragmentation of media authority and its link to right-wing populism and cyber islamophobia. Jurnal Komunikasi: Malaysian Journal of Communication, 37(3), 231-243. https://doi.org/10.17576/JKMJC-2021-3703-13

Bencsik, A., \& Machova, R. (2016). Knowledge sharing problems from the viewpoint of intergeneration management. ICMLG2016-4th International Conferenceon Management, Leadership and Governance: ICMLG2016, 42.

Bungin, B. (2013). Metodologi Penelitian Kuantitatif. Kencana Prenada Media Group.

Candrasari, Y. (2021). Nonverbal Communication Reconstruction on Facebook. Jurnal The Messenger, 13(1), 94. https://doi.org/10.26623/themessenger.v13i1.1000

Chen, C.-P. (2014). Forming digital self and parasocial relationships on YouTube. Journal of Consumer Culture, 16(1), 232-254. https://doi.org/10.1177/1469540514521081

Chen, H. (2018). College-Aged Young Consumers' Perceptions of Social Media Marketing: The Story of Instagram. Journal of Current Issues and Research in Advertising, 39(1), 22-36. https://doi.org/10.1080/10641734.2017.1372321

Denson, T. F., DeWall, C. N., \& Finkel, E. J. (2012). Self-control and aggression. Current Directions in Psychological Science, 21(1), 20-25.

Duntari, R. A. A., \& Riska Hidayat, R. I. (2018). Polemik "Kids Jaman Now" Ditinjau Dari Aspek Perkembangan Sosial. Fokus, 1(Januari), 27-36.

Ellison, N. B., Gray, R., Lampe, C., \& Fiore, A. T. (2014). Social capital and resource requests on Facebook. New Media \& Society, 16(7), 1104-1121. https://doi.org/10.1177/1461444814543998

Faiqah, F., Nadjib, M., \& Amir, A. S. (2016). Youtube Sebagai Sarana Komunikasi Bagi Komunitas Makassarvidgram. Jurnal Komunikasi KAREBA, 16(1), 259-272. https://doi.org/10.1080/14639947.2015.1006801

Fiaji, N. A. (2018). Pergeseran Nilai Moral Dalam Meme "Kids Jaman Now." WASKITA: Jurnal Pendidikan Nilai Dan Pembangunan Karakter., 2(1). https://doi.org/https://doi.org/10.21776/ub.waskita.2018.002.01.7

Gangneux, J. (2019). Logged in or locked in? Young adults' negotiations of social media platforms and their features. Journal of Youth Studies, 22(8), 1053-1067. https://doi.org/10.1080/13676261.2018.1562539

García Jiménez, A., \& Montes Vozmediano, M. (2020). Subject matter of videos for teens on YouTube. International Journal of Adolescence and Youth, 25(1), 63-78. https://doi.org/10.1080/02673843.2019.1590850

Hall, S. (1997). Theory of Representation. Sage Publications.

Hidayatullah, S., Waris, A., \& Devianti, R. C. (2018). Perilaku Generasi Milenial dalam Menggunakan Aplikasi Go-Food. Jurnal Manajemen Dan Kewirausahaan, 6(2), 240-249. https://doi.org/10.26905/jmdk.v6i2.2560

Ibrahim, S. (2011). Kritik Budaya Komunikasi. Yogyakarta: Jalasutra.

Jatmiko, L. D. (2020). APJII: 196.7 Juta Warga Indonesia Sudah Melek Internet. bisnis.com, 1-9.

Khamis, S., Ang, L., \& Welling, R. (2017). Self-branding, 'micro-celebrity' and the rise of Social Media Influencers. Celebrity Studies, 8(2), 191-208. https://doi.org/10.1080/19392397.2016.1218292

Khan, M. L. (2017). Social media engagement: What motivates user participation and consumption on YouTube? Computers in Human Behavior, 66, 236-247. https://doi.org/https://doi.org/10.1016/j.chb.2016.09.024 
Kuncoro, A. M., Putri, A. O., \& Pradita, A. (2018). Vlogger Sebagai Saluran Menuju Generasi Milenial Produktif Indonesia. Sinergitas Quadruple Helix: E-Business Dan Fintech Sebagai Daya Dorong Pertumbuhan Ekonomi Lokal, 193-199.

Lee, S., \& Kim, E. (2020). Influencer marketing on Instagram: How sponsorship disclosure, influencer credibility, and brand credibility impact the effectiveness of Instagram promotional post. Journal of Global Fashion Marketing, 11(3), 232249. https://doi.org/10.1080/20932685.2020.1752766

Medcom.id. (2017). Mengenal Generasi Milenial dan “Kids Zaman Now.” 1-11.

Mosley, D. V., Abreu, R. L., Ruderman, A., \& Crowell, C. (2017). Hashtags and hiphop: exploring the online performances of hip-hop identified youth using Instagram. Feminist Media Studies, 17(2), 135-152. https://doi.org/10.1080/14680777.2016.1197293

Mulyadi, U., \& Fitriana, L. (2018). Hashtag (\#) as Message Identity in Virtual Community. Jurnal The Messenger, 10(1), 44. https://doi.org/10.26623/themessenger.v10i1.671

Musya'adah, U. (2018). Arti Seorang Pendidik Untuk “Kids Zaman Now" Analisa Kritis Terhadap Pendidik dalam Pendidikan Islam. Modeling, 5(2), 157-174. http://jurnal.stitnualhikmah.ac.id/index.php/modeling/article/view/332.

Naldo, H. W. S. (2018). Studi Observasi terhadap Penggunaan Aplikasi LINE oleh Generasi Millenial. Jurnal Sosial Humaniora Terapan, 1(1), 32-40. https://doi.org/10.7454/jsht.v1i1.33

Nurhadi, Z. F., Salamah, U., \& Yuniar, A. A. (2020). Motif Penggunaan Youtube Sebagai Media Informasi. Commed: Jurnal Komunikasi Dan Media, 4(2), 170190.

Nuriana, D., Rizkiyah, I., Efendi, L., Wibowo, H., \& Raharjo, S. T. (2019). Generasi Baby Boomers (Lanjut Usia) Dalam Menghadapi Era Revolusi Industri 4.0. Focus : Jurnal Pekerjaan Sosial, https://doi.org/https://doi.org/10.24198/focus.v2i1.23117

Palinoan, I. Y. (2017). Dampak Tayangan Vlog Di Youtube Terhadap Gaya Hidup Hedonis Siswa. Jurnal Ilmu Komunikasi Universitas Mulawarman.[Online], 5(2), 215-225.

Parry, E., \& Urwin, P. (2011). Generational differences in work values: A review of theory and evidence. International Journal of Management Reviews, 13(1), 7996.

Pires, F., Masanet, M. J., \& Scolari, C. A. (2021). What are teens doing with YouTube? Practices, uses and metaphors of the most popular audio-visual platform. Information Communication and Society, 24(9), 1175-1191. https://doi.org/10.1080/1369118X.2019.1672766

Prianto, J. (2014). Cantik: Panduan Lengkap Merawat Kulit Wajah. Gramedia Pustaka Utama.

Putra, Y. S. (2018). Theoritical Review: Teori Perbedaan Generasi. Among Makarti, 9(1), 123-134.

Raby, R., Caron, C., Théwissen-LeBlanc, S., Prioletta, J., \& Mitchell, C. (2018). Vlogging on YouTube: the online, political engagement of young Canadians advocating for social change. Journal of Youth Studies, 21(4), 497-514. https://doi.org/10.1080/13676261.2017.1394995

Rahman, T., Nurnisya, F. Y., Nurjanah, A., \& Hifziati, L. (2021). Hijrah and the articulation of islamic identity of indonesian millenials on instagram. Jurnal 
Komunikasi: Malaysian Journal of Communication, 37(2), 154-170. https://doi.org/10.17576/JKMJC-2021-3702-10

Rahmawati, A. (2021). Manufacturing Authenticity: The Rise of Indonesian MicroCelebrities on Instagram. Jurnal The Messenger, 13(1), 108. https://doi.org/10.26623/themessenger.v13i1.999

Rashid, J. A., Aziz, A. A., Rahman, A. A., Saaid, S. A., Ahmad, Z., \& Zainodin, W. H. W. (2020). The influence of mobile phone addiction on academic performance among teenagers. Jurnal Komunikasi: Malaysian Journal of Communication, 36(3), 408-424. https://doi.org/10.17576/JKMJC-2020-3603-25

Rootsi, S., Behar, D. M., Järve, M., Lin, A. A., Myres, N. M., Passarelli, B., Poznik, G. D., Tzur, S., Sahakyan, H., \& Pathak, A. K. (2013). hylogenetic applications of whole Y-chromosome sequences and the Near Eastern origin of Ashkenazi Levites. Nature Communications, 4(1), 1-9.

Rosidi, I. (2020). Consuming Representations of Korean TV Dramas among Indonesian Muslim Youth. Jurnal The Messenger, 12(2), 111. https://doi.org/10.26623/themessenger.v12i2.2115

Sari, E. A. (2020). Pengaruh Aktifitas Penelusuran Informasi Terhadap Jejak Digital Di Youtube Bagi Generasi Millenial. BIBLIOTIKA: Jurnal Kajian Perpustakaan Dan Informasi, 4(1), 42-55.

Schwartz, S. J., Zamboanga, B. L., Meca, A., \& Ritchie, R. A. (2012). Identity around the world: An overview. New Directions for Child and Adolescent Development, 2012(138), 1-18.

Scolari, C. A., \& Fraticelli, D. (2017). The case of the top Spanish YouTubers: Emerging media subjects and discourse practices in the new media ecology. Convergence, 25(3), 496-515. https://doi.org/ttps://doi.org/10.1177/1354856517721807

Scolari, C., Masanet, M.-J., Guerrero-Pico, M., \& Establés, M.-J. (2018). Transmedia literacy in the new media ecology: Teens' transmedia skills and informal learning strategies. El Profesional de La Informacion, 27(4), 801-812. https://doi.org/https://doi.org/10.3145/epi.2018.jul.09

Sianipar, A. P. (2013). Pemanfaatan youtube di kalangan mahasiswa. Jurnal Pendidikan, 2.

Soerjoatmodjo, S. P. G. (2018). Membangun Karakter Kebangsaan Kids Zaman Now. Infobintaro.

Suherman, M. (2016). Efektivitas Strategi Permainan Dalam Mengembangkan SelfControl Siswa. Jurnal Penelitian Pendidikan, 16(2), 194-201.

Supratman, L. P. (2018). Penggunaan Media Sosial oleh Digital Native. Jurnal Ilmu Komunikasi, 15(1), 47-60. https://doi.org/10.24002/jik.v15i1.1243

Suryadi, B. (2015). Generasi y: karakteristik, masalah, dan peran konselor. Seminar dan Workshop Internasional MALINDO 4. https://repository.uinjkt.ac.id/dspace/handle/123456789/34351

Syafrida Febriyanti, R. T. (2019). Youth Identity in Social Media (Virtual Ethnography Studies of Youth Identity Construction on "Kids Jaman Now" Content Youtube Channels). 2018(2018), 520-526. https://doi.org/10.11594/nstp.2019.0271

Syam, H. M., \& Nurrahmi, F. (2020). "I Don't Know If It Is Fake or Real News" How Little Indonesian University Students Understand Social Media Literacy. Jurnal Komunikasi: Malaysian Journal of Communication, 36(2), 92-105. https://doi.org/10.17576/JKMJC-2020-3602-06 
Syukron, A. A. (2018). Pendidikan Moral Kids Zaman Now dalam Perspektif Islam. JPAI, 4(2), 159-179. https://doi.org/https://doi.org/10.18860/jpai.v4i2.4620

Tutiasri, R. P., \& Kusuma, A. (2020). Millennial generation and family literacy within the dissemination of hoax in Whatsapp group. Informasi, 50(2), 153-164.

Vromen, A., Xenos, M. A., \& Loader, B. (2015). Young people, social media and connective action: from organisational maintenance to everyday political talk. Journal of Youth Studies, 18(1), 80-100. https://doi.org/10.1080/13676261.2014.933198

West, R., \& Turner, L. (2014). Pengantar Teori Komunikasi: Analisis dan Aplikasi, Terjemah oleh Brian Marswendy. Jakarta: Salemba Humanika.

Widika, T. (2018). Sejarah Berdirinya YouTube--Sejarah Dunia. Canacantya. https://canacantya.wordpress.com/sejarah/sejarah-berdirinya-YouTube/

Yusuf, S. (2016). Psikologi perkembangan anak \& remaja. Remaja Rosdakarya.

Yuswohady. (2016). Millennial Trends 2016. Yuswohady. https://www.yuswohady.com/2016/01/17/millennial-trends-2016/

Zulfah, S. (2018). Pengaruh Perkembangan Teknologi Informasi Lingkungan (Studi Kasus Kelurahan Siti Rejo I Medan). Buletin Utama Teknik, 13(2), 2. 